\title{
PENGARUH TINGKAT PROTEIN DENGAN IMBANGAN ENERGI YANG SAMA TERHADAP PERTUMBUHAN AYAM LEHER GUNDUL DAN NORMAL SAMPAI UMUR 10 MINGGU
}

\section{THE EFFECT OF PROTEIN LEVELS WITH THE SAME ENERGY BALANCE ON THE GROWTH OF NAKED NECK AND NORMAL CHICKEN UNTIL THE AGE OF 10 WEEKS}

\author{
Harwi Kusnadi ${ }^{1 *}$, Jafendi Hasoloan Purba Sidadolog ${ }^{2}$, Zuprizal $^{2}$, dan Heru Ponco Wardono ${ }^{3}$ \\ ${ }^{1}$ BPTP Bengkulu, Jl. Irian km 6,5, Kota Bengkulu, 38119 \\ ${ }^{2}$ Fakultas Peternakan, Universitas Gadjah Mada, Jl. Fauna No. 3, Bulaksumur, Yogyakarta, 55281 \\ ${ }^{3}$ BPTP Maluku Utara, J1. Raya Sofifi-Weda km 14, Kusu, Sofifi, Tidore, Kepulauan Maluku Utara
}

\section{INTISARI}

Tujuan penelitian ini adalah untuk mengetahui pengaruh tingkat protein dengan imbangan energi yang sama, pengaruh kondisi bulu terhadap pertumbuhan dan interaksinya pada ayam Leher Gundul (Legund) dan ayam normal sampai umur 10 minggu. Penelitian ini dilakukan pada faktor pakan dengan tiga macam perlakuan pakan yaitu dengan imbangan kandungan protein dan energi (1:150) yaitu: P1 (20,94\% protein : $3.139,43 \mathrm{kcal} / \mathrm{kg}$ energi), P2 (18,91\% protein : $2.839,20 \mathrm{kcal} / \mathrm{kg}$ energi), P3 (17,32\% protein : 2.596,28 kcal/kg energi). Pemberian pakan dan air minum secara ad libitum. Pengaruh kondisi bulu yaitu ayam Leher Gundul (Legund) dan ayam normal. Penelitian ini menggunakan day old chicken (DOC) ayam Legund sebanyak 84 ekor dan DOC ayam normal sebanyak 72 ekor. Data yang diambil antara lain berat badan, pertambahan berat badan, konsumsi pakan, dan konversi pakan. Data dianalisis dengan Rancangan Acak Lengkap pola faktorial. Hasil penelitian menunjukkan bahwa tidak ada interaksi antara pengaruh pakan dengan imbangan protein-energi yang sama dan pengaruh kondisi bulu pada konsumsi dan konversi pakan. Pakan dengan imbangan protein-energi yang sama berpengaruh sangat nyata $(\mathrm{P}<0,01)$ terhadap berat badan sampai minggu ke-10, terhadap pertambahan berat badan kecuali minggu ke-2-4, terhadap konsumsi pakan sampai minggu ke-4-6, terhadap konversi pakan kecuali minggu ke-8-10. Perbedaan kondisi bulu tidak berpengaruh terhadap berat badan, pertambahan berat badan, konsumsi pakan kecuali minggu ke-8-10, dan konversi pakan. Kesimpulan penelitian ini bahwa pakan dengan imbangan protein-energi $20,94 \%$ dan energi $3.139,43 \mathrm{kcal} / \mathrm{kg}$ paling baik untuk menghasilkan berat badan dan pertambahan berat badan ayam Legund maupun ayam normal sampai umur 10 minggu. Pertumbuhan ayam Legund sama dengan ayam normal sampai umur 10 minggu. Pemunculan interaksi antara pengaruh tingkat protein dengan imbangan energi yang sama dan pengaruh kondisi bulu tidak terjadi pada konsumsi pakan dan konversi pakan ayam Legund dan ayam normal sampai umur 10 minggu.

(Kata kunci: Imbangan protein-energi, Pertumbuhan, Ayam Leher Gundul, Ayam normal)

\section{ABSTRACT}

The purpose of this study was to determine the effect of protein levels with the same energy balance and the effect feather condition on the growth and interaction of Naked Neck chicken and normal chicken until the age of 10 weeks. This study was conducted on feed factor, treatment of three feeding with protein and energy content balance (1:150), P1 (20.94\% protein : $3139.43 \mathrm{kcal} / \mathrm{kg}$ energy), P2 (18.91\% protein : $2839.20 \mathrm{kca} / \mathrm{kg}$ energy), P3 (17.32\% protein : $2596.28 \mathrm{kcal} / \mathrm{kg}$ energy). Feed and drinking water were ad libitum. The effect of feather condition is Naked Neck chicken and normal chicken. This study was using 84 DOC Naked Neck chicken and 72 DOC normal chickens. Data taken include body weight, the weight gain, feed consumption and feed convertion. Data were analyzed by factorial completely randomized design pattern. The results showed that there was no interaction between the effect of feed with protein-energy balance and the effect of feather condition on feed consumption, and feed convertion. Feeding with same protein-energy balance showed highly significant $(P<0.01)$ on body weight until the age of 10 weeks, the weight gain except 2-4 week of age, the feed consumption until 4-6 week of age, the feed convertion except 8-10 week of age. The differences of the feathers conditions do not affect on weight, the weight gain, feed consumption except 8-10 weeks, and feed convertion. From this study could be concluded that feed with protein-energy balance (20.94\% : $3139.43 \mathrm{kcal} / \mathrm{kg}$ ) is highest to support the growth of Naked Neck chickens and normal chicken until the age of 10 weeks. The growth of Naked Neck chickens and normal chicken were same until the age of 10 weeks. The appearance interaction between the effect of the protein level with the same energy balance and the effect of feather conditions do not occur in feed consumption and feed convertion of Naked Neck chicken and normal chicken until the age of 10 weeks.

(Keywords: Protein-energy balance, Growth, Naked Neck chicken, Normal chicken)

\footnotetext{
* Korespondensi (corresponding author):

Telp. +62 87839790131

E-mail: harwi_kusnadi@yahoo.com
} 


\section{Pendahuluan}

Ayam kampung merupakan ayam lokal di Indonesia yang kehidupannya sudah melekat dengan masyarakat. Ayam kampung juga dikenal dengan sebutan ayam buras (bukan ras). Penampilan ayam kampung sangat beragam, begitu pula sifat genetiknya, penyebarannya juga sangat luas karena dapat dijumpai di kota maupun di desa. Ayam kampung berkembang cukup baik dari tahun ke tahun. Hal ini terlihat dari populasi ayam kampung pada tahun 2011 sebesar 264,34 juta ekor sehingga terjadi peningkatan 2,64\% dari tahun 2010 (Ditjenak, 2012). Ayam kampung sangat berarti bagi masyarakat karena kontribusinya dalam meningkatkan pendapatan keluarga dan memenuhi kebutuhan gizi dari daging dan telur yang dihasilkan. Di beberapa daerah di Indonesia ayam kampung sangat dibutuhkan oleh masyarakat dalam acara keagamaan, adat istiadat dan hobi sehingga pembudidayaannya perlu ditingkatkan (Nitis, 2006).

Penampilan ayam dengan kondisi bulu dan pertumbuhan yang terbatas pada bagian leher dan sekitarnya disebut ayam Leher Gundul atau Legund (Naked Neck fowl) (Sidadolog, 1991). Penampilan tersebut menjadikan ayam Legund lebih lancar dalam pembuangan panas tubuh sehingga lebih toleran terhadap lingkungan dengan temperatur tinggi. Kondisi tidak adanya bulu pada leher pada daerah dengan temperatur tinggi menjadikan ayam Legund lebih toleran terhadap pemberian pakan dengan kandungan energi yang rendah dibanding dengan ayam bulu normal sehingga dengan pakan yang sama memiliki potensi pertumbuhan yang lebih baik dibanding dengan ayam normal (Sidadolog, 1991). Dengan keistimewaan tersebut ayam Legund mempunyai potensi yang baik untuk dikembangkan di daerah tropis.

Permasalahan utama dalam pengembangan ayam kampung adalah penampilan yang kurang optimal dan rendahnya produktivitas. Penampilan ternak ditentukan oleh faktor genetik dan faktor lingkungan. Faktor genetik didapatkan dari induk betina dan pejantan tetuanya, sedangkan faktor lingkungan salah satunya adalah pakan. Potensi genetik ternak akan ditampilkan apabila ditunjang dengan nutrisi pakan yang cukup. Penampilan yang kurang optimal dan produktivitas yang rendah pada ayam kampung salah satunya disebabkan pemberian pakan dengan nutrisi yang tidak memenuhi kebutuhan ternak karena biasanya peternak memberi makan ayam dengan sisa makan dan dedak padi sebagai tambahannya. Peningkatan populasi, produksi dan efisiensi usaha ayam kampung, perlu ditingkatkan dari tradisional ke arah agribisnis (Zakaria, 2004). Tetapi perlu diperhatikan dalam biaya produksi sehingga biaya yang dikeluarkan sebanding dengan hasil yang diperoleh. Dalam usaha peternakan unggas biaya untuk pakan mencapai 65-70\% dari total biaya produksi (Zuprizal, 2006), sehingga harga bahan pakan sangat menentukan biaya produksi. Oleh karena itu perlu diupayakan penghematan untuk menekan biaya produksi.

Pada fase pertumbuhan ayam memerlukan protein dan energi yang tinggi sesuai dengan kebutuhannya karena protein dan energi merupakan nutrisi makanan yang sangat berperan dalam pertumbuhan. Pertumbuhan ayam lokal yang relatif rendah dan hanya mencapai bobot hidup $0,5 \mathrm{~kg} / \mathrm{ekor}$ pada umur 7 minggu, diduga membutuhkan protein ransum yang lebih rendah dari kebutuhan protein ayam broiler yang dapat mencapai bobot hidup 2,5 kg pada umur yang sama, namun, bila kadar protein ransum terlalu rendah akan menyebabkan pertumbuhan yang rendah pula (Bregendahl et al., 2002). Sebaliknya bila tingkat protein ransum terlalu tinggi maka pertumbuhan akan meningkat, namun tidak sepadan dengan biaya peningkatan protein ransum (Swennen et al., 2004).

Penelitian tentang pemberian pakan dengan imbangan protein-energi pada ayam kampung telah banyak dilakukan. Akan tetapi pemberian tingkat protein dan energi pakan yang tepat masih perlu dilakukan penelitian sejenis pada berbagai macam jenis ayam kampung diantaranya pada ayam Legund dan dibandingkan dengan ayam normal. Sehubungan dengan uraian permasalahan di atas perlu dilakukan penelitian pengaruh tingkat protein dengan imbangan energi yang sama, pengaruh kondisi bulu terhadap pertumbuhan dan interaksinya pada ayam Legund dan ayam normal sampai umur 10 minggu.

\section{Materi dan Metode}

\section{Materi}

Penelitian ini menggunakan day old chicken (DOC) ayam Legund sebanyak 84 ekor dan DOC ayam normal sebanyak 72 ekor. Bahan pakan yang digunakan antara lain jagung kuning giling, bungkil kedelai, dedak padi, meat bone meal, tepung ikan, garam, top mix, $\mathrm{CaCO}_{3}$, lysin, metionin, dan minyak crude palm oil (CPO). Formula pakan penelitian disajikan pada Tabel 1 .

Pakan yang digunakan dalam penelitian ini terdiri dari tiga macam ransum dengan imbangan kandungan protein dan energi (1:150) yaitu: $\mathrm{P} 1=$ protein pakan $20,94 \%$ dan energi $3.139,43 \mathrm{kcal} / \mathrm{kg}, \mathrm{P} 2=$ protein pakan $18,91 \%$ dan energi $2.839,20 \mathrm{kcal} / \mathrm{kg}, \mathrm{P} 3$ = protein pakan $17,32 \%$ dan energi $2.596,28 \mathrm{kcal} / \mathrm{kg}$.

\section{Metode}

Day old chicken (DOC) ayam Legund sebanyak 84 ekor dibagi menjadi tiga kelompok 
Tabel 1. Bahan pakan, kandungan nutrisi, dan formula pakan penelitian (feed ingredient, nutritional content and research feed formula)

\begin{tabular}{|c|c|c|c|}
\hline \multirow{2}{*}{ Bahan pakan (feed stuff) } & \multicolumn{3}{|c|}{ Formula pakan penelitian $(\%)$ (research feed formula $(\%))$} \\
\hline & $\mathrm{P} 1$ & $\mathrm{P} 2$ & P3 \\
\hline Jagung kuning giling (milled yellow corn) & 46,50 & 40,00 & 29,00 \\
\hline Bungkil kedelai (soybean meal) & 28,00 & 23,00 & 21,50 \\
\hline Dedak padi (rice bran) & 12,00 & 27,50 & 42,50 \\
\hline Meat bone meal & 3,00 & 2,50 & 1,00 \\
\hline Tepung Ikan (fish meal) & 3,50 & 2,50 & 1,00 \\
\hline Garam (salt) & 0,25 & 0,25 & 0,25 \\
\hline Top Mix & 0,25 & 0,25 & 0,25 \\
\hline $\mathrm{CaCO}_{3}$ & 1,00 & 1,00 & 1,00 \\
\hline L-lysine-HCL & 0,25 & 0,25 & 0,25 \\
\hline DL-methionine & 0,25 & 0,25 & 0,25 \\
\hline Minyak CPO (CPO oil) & 5,00 & 1,50 & 0,00 \\
\hline Filler & 0,00 & 1,00 & 3,00 \\
\hline Total & 100,00 & 100,00 & 100,00 \\
\hline \multicolumn{4}{|l|}{ Kandungan nutrien (nutritional content): } \\
\hline $\mathrm{ME}(\mathrm{kcal} / \mathrm{kg})$ & $3.139,43$ & $2.839,20$ & $2.596,28$ \\
\hline PK $(\%)$ & 20,94 & 18,91 & 17,32 \\
\hline SK $(\%)$ & 4,50 & 7,30 & 9,90 \\
\hline LK $(\%)$ & 3,70 & 4,20 & 4,50 \\
\hline $\mathrm{Ca}(\%)$ & 0,80 & 0,70 & 0,70 \\
\hline $\operatorname{Pav}(\%)$ & 0,30 & 0,30 & 0,30 \\
\hline Abu $(\%)(\operatorname{ash}(\%))$ & 5,30 & 6,40 & 7,40 \\
\hline L-lysine-HCL (\%) & 1,35 & 1,27 & 1,23 \\
\hline DL-methionine $(\%)$ & 0,59 & 0,58 & 0,57 \\
\hline Protein : Energi & $(1: 150)$ & $(1: 150)$ & $(1: 150)$ \\
\hline
\end{tabular}

P1: 20,94\% protein : $3.139,43 \mathrm{kcal} / \mathrm{kg}$ energi, $\mathrm{P} 2: 18,91 \%$ protein : $2.839,20 \mathrm{kcal} / \mathrm{kg}$ energi, $\mathrm{P} 3: 17,32 \%$ protein : $2.596,28 \mathrm{kcal} / \mathrm{kg}$ energi.

CPO: crude palm oil, ME: metabolizable energy, PK: protein kasar (crude protein), SK: serat kasar (crude fiber), LK: lemak kasar (extract ether), Ca: calcium, Pav: phosphorus available.

sesuai perlakuan pakan dengan enam kali ulangan sehingga masing-masing kelompok berisi 4 atau 5 ekor, demikian juga DOC ayam normal sebanyak 72 ekor dibagi menjadi tiga bagian sesuai perlakuan pakan dengan enam kali ulangan sehingga masingmasing kelompok berisi 4 ekor. DOC masingmasing kelompok ditempatkan pada kandang kelompok yang dilengkapi dengan tempat pakan, tempat minum dan lampu pijar 25 watt. Pemberian pakan dan air minum secara adlibitum. Penimbangan berat badan dan sisa pakan dilakukan setiap minggu. Ayam dipelihara sampai umur 10 minggu.

Data yang diambil meliputi: berat badan (BB, $\mathrm{g}$ ), konsumsi pakan (g), pertambahan berat badan $(\mathrm{PBB}, \mathrm{g})$ dari $(\mathrm{BB}=\mathrm{BB}$ akhir $-\mathrm{BB}$ awal $)$, dan konversi pakan (perbandingan konsumsi pakan (g) dan pertambahan berat badan $(\mathrm{g})$ ).

Data berat badan, konsumsi pakan, dan konversi pakan dianalisis dengan Rancangan Acak Lengkap pola faktorial. Faktor 1 yaitu pengaruh pakan dengan kandungan protein berbeda dan imbangan energi yang sama dengan tiga kombinasi. Faktor 2 yaitu pengaruh perbedaan kondisi bulu dengan dua kombinasi. Individu sebagai replikasi pada berat badan, kelompok pada konsumsi pakan dan konversi pakan. Model matematika yang digunakan adalah:

$$
Y_{i j k}=\mu+B_{i}+P_{j}+B P_{i j}+E_{i j k}
$$

Keterangan :

$\mathrm{Y}_{\mathrm{ijk}} \quad=$ nilai pengamatan individu 
$\mu \quad=$ rerata populasi

$\mathrm{B}_{\mathrm{i}} \quad=$ pengaruh kondisi bulu ke-i $(1,2)$

$\mathrm{P}_{\mathrm{j}} \quad=$ pengaruh pakan ke-j $(1,2,3)$

$\mathrm{BP}_{\mathrm{ij}} \quad=$ pengaruh interaksi kondisi bulu ke-i $(1,2)$ dan pakan ke-j $(1,2,3)$

$\mathrm{E}_{\mathrm{ijk}} \quad=$ kesalahan baku dari individu ke-k dengan kondisi bulu ke-i dan pakan ke-j.

Apabila hasil analisis menunjukkan pengaruh yang nyata, dilanjutkan dengan uji Duncan's new Multiple Range Test (DMRT).

\section{Hasil dan Pembahasan}

\section{Berat badan}

Rerata berat badan ayam hasil penelitian sampai umur 10 minggu disajikan pada Tabel 2. Berat badan DOC dipilih sama pada masing-masing perlakuan. Berat badan DOC sangat penting sebelum perlakuan pakan karena dapat berpengaruh terhadap berat badan pada minggu selanjutnya. Pertumbuhan berat badan pada umur berikutnya sangat ditentukan oleh berat badan sebelumnya (Sidadolog, 2001).

Tabel 2. Rerata berat badan ayam (g/ekor) pengaruh umur, kondisi bulu dan pakan (average chicken weight ( $g /$ chicken) the effect of age, feather condition and feed)

\begin{tabular}{|c|c|c|c|c|c|}
\hline \multirow{2}{*}{$\begin{array}{c}\text { Umur } \\
\text { (age) } \\
\text { (minggu) } \\
\text { (week) }\end{array}$} & \multirow{2}{*}{$\begin{array}{l}\text { Kondisi } \\
\text { bulu } \\
\text { (feather } \\
\text { condition) }\end{array}$} & \multicolumn{3}{|c|}{ Pakan (feed) } & \multirow{2}{*}{$\begin{array}{c}\text { Rerata kondisi } \\
\text { bulu (average of } \\
\text { feather condition) }\end{array}$} \\
\hline & & P1 & $\mathrm{P} 2$ & $\mathrm{P} 3$ & \\
\hline \multirow{3}{*}{$\begin{array}{l}\text { Awal } \\
\text { (early) }\end{array}$} & Legund & $29,61 \pm 2,76$ & $29,19 \pm 2,48$ & $28,80 \pm 2,89$ & $29,20 \pm 2,71$ \\
\hline & Normal & $28,76 \pm 3,92$ & $29,79 \pm 3,18$ & $28,77 \pm 3,06$ & $29,11 \pm 3,39$ \\
\hline & $\begin{array}{l}\text { Rerata } \\
{\text { (average })^{\mathrm{ns}}}\end{array}$ & $29,18 \pm 3,34$ & $29,49 \pm 2,83$ & $28,79 \pm 2,97$ & $29,15 \pm 3,05^{\mathrm{ns}}$ \\
\hline \multirow{3}{*}{2} & Legund & $73,39 \pm 17,63$ & $69,04 \pm 11,01$ & $67,30 \pm 15,27$ & $69,91 \pm 14,64$ \\
\hline & Normal & $70,76 \pm 11,81$ & $74,08 \pm 15,86$ & $63,63 \pm 11,65$ & $69,49 \pm 13,11$ \\
\hline & $\begin{array}{l}\text { Rerata } \\
(\text { (average)** }\end{array}$ & $72,07 \pm 14,72^{\mathrm{a}}$ & $71,56 \pm 13,44^{\mathrm{ab}}$ & $65,47 \pm 13,46^{\mathrm{c}}$ & $69,69 \pm 13,87^{\mathrm{ns}}$ \\
\hline \multirow{3}{*}{4} & Legund & $159,27 \pm 36,85$ & $151,86 \pm 26,52$ & $148,52 \pm 29,42$ & $153,22 \pm 30,93$ \\
\hline & Normal & $164,98 \pm 28,87$ & $160,12 \pm 40,29$ & $147,03 \pm 31,51$ & $157,38 \pm 33,56$ \\
\hline & $\begin{array}{l}\text { Rerata } \\
\text { (average)* }\end{array}$ & $162,12 \pm 32,86^{\mathrm{a}}$ & $155,99 \pm 33,41^{\mathrm{ab}}$ & $147,78 \pm 30,47^{b}$ & $155,29 \pm 32,25^{\mathrm{ns}}$ \\
\hline \multirow{3}{*}{6} & Legund & $299,81 \pm 66,56$ & $277,68 \pm 43,14$ & $257,60 \pm 62,84$ & $278,36 \pm 57,51$ \\
\hline & Normal & $300,40 \pm 53,73$ & $293,19 \pm 52,74$ & $258,95 \pm 41,76$ & $284,18 \pm 49,41$ \\
\hline & $\begin{array}{l}\text { Rerata } \\
(\text { (average)** }\end{array}$ & $300,11 \pm 60,14^{\mathrm{a}}$ & $285,44 \pm 47,94^{\mathrm{ab}}$ & $258,28 \pm 52,30^{\mathrm{b}}$ & $281,27 \pm 53,46^{\mathrm{ns}}$ \\
\hline \multirow{3}{*}{8} & Legund & $473,39 \pm 98,65$ & $429,55 \pm 74,11$ & $370,74 \pm 103,82$ & $424,56 \pm 92,19$ \\
\hline & Normal & $472,41 \pm 80,08$ & $452,33 \pm 93,52$ & $394,71 \pm 72,52$ & $439,81 \pm 82,04$ \\
\hline & $\begin{array}{l}\text { Rerata } \\
(\text { average)** }\end{array}$ & $472,89 \pm 89,36^{\mathrm{a}}$ & $440,94 \pm 83,81^{\mathrm{ab}}$ & $382,72 \pm 88,17^{\mathrm{c}}$ & $432,19 \pm 87,12^{\mathrm{ns}}$ \\
\hline \multirow{3}{*}{10} & Legund & $654,84 \pm 136,47$ & $578,69 \pm 109,03$ & $513,50 \pm 143,24$ & $582,35 \pm 129,58$ \\
\hline & Normal & $648,91 \pm 121,24$ & $637,84 \pm 118,35$ & $554,97 \pm 104,65$ & $613,91 \pm 114,75$ \\
\hline & $\begin{array}{l}\text { Rerata } \\
\text { (average)** }\end{array}$ & $651,88 \pm 128,86^{\mathrm{a}}$ & $608,27 \pm 113,69^{\mathrm{ab}}$ & $534,24 \pm 123,95^{\mathrm{b}}$ & $598,13 \pm 122,16^{\mathrm{ns}}$ \\
\hline \multicolumn{6}{|c|}{$\begin{array}{l}\mathrm{P} 1: 20,94 \% \text { protein }: 3.139,43 \mathrm{kcal} / \mathrm{kg} \text { energi, } \mathrm{P} 2: 18,91 \% \text { protein }: 2.839,20 \mathrm{kcal} / \mathrm{kg} \text { energi, } \mathrm{P} 3: 17,32 \% \\
\text { protein }: 2.596,28 \mathrm{kcal} / \mathrm{kg} \text { energi. } \\
\text { a,b,c } \\
\text { Superskrip yang berbeda pada baris yang sama menunjukkan perbedaan yang nyata }(\mathrm{P}<0,05) \text { dan sangat } \\
\text { nyata }(\mathrm{P}<0,01)(\text { different superscripts at the same row indicate significant differences }(P<0.05) \text { and } \\
\text { highly significant }(P<0.01)) \text {. }\end{array}$} \\
\hline \multicolumn{6}{|c|}{ ns Berbeda tidak nyata (non significant). } \\
\hline \multicolumn{6}{|c|}{ * Berbeda nyata (significant) } \\
\hline
\end{tabular}


Pada Tabel 2 menunjukkan bahwa tidak ada interaksi antara pengaruh perbedaan tingkat protein pakan dengan imbangan energi yang sama dan pengaruh kondisi bulu pada berat badan sampai minggu ke-10, untuk itu pembahasan dilakukan pada masing-masing faktor.

Perbedaan tingkat protein pakan dengan imbangan energi yang sama menghasilkan berat badan yang berbeda sangat nyata $(\mathrm{P}<0,01)$ sampai minggu ke-10. Hasil ini menunjukkan bahwa ketiga perlakuan pakan memberikan reaksi yang berbeda dan menghasilkan berat badan yang berbeda. Pada Tabel 2 dapat dilihat bahwa P1 menghasilkan berat badan paling tinggi sedangkan P3 menghasilkan berat badan paling rendah. Pakan dengan tingkat protein dan energi paling tinggi memberikan kesempatan lebih baik dalam memanfaatkan protein dan energi yang dikonsumsi untuk menghasilkan berat badan yang lebih tinggi daripada pakan dengan tingkat protein dan energi yang lebih rendah.

Hasil penelitian Dewi et al. (2009) bahwa ayam kampung diberi pakan mengandung imbangan energi dan protein lebih tinggi menghasilkan berat badan lebih tinggi secara nyata $(\mathrm{P}<0,05)$ dibanding pakan yang mengandung imbangan energi dan protein lebih rendah pada umur 8 minggu. Dewi dan Wijana (2011) melaporkan bahwa pakan dengan imbangan protein-energi 22\%-3.100 $\mathrm{kcal} / \mathrm{kg}$, 20\%-3.000 kcal $/ \mathrm{kg}, \quad 18 \%-2.900 \mathrm{kcal} / \mathrm{kg}$, dan $16 \%-2.800 \mathrm{kcal} / \mathrm{kg}$, menghasilkan berat badan yang berbeda nyata $(\mathrm{P}<0,05)$ yaitu $706,18 \mathrm{~g}, 693,25 \mathrm{~g}$, 699,40 g, dan 635,50 g. Semakin rendah kandungan protein-energinya, maka semakin rendah berat badan ayam yang dihasilkan.

Perbedaan kondisi bulu pada ayam Legund dan ayam normal mulai DOC sampai umur 10 minggu menghasilkan berat badan yang berbeda tidak nyata. Hal ini menunjukkan bahwa sampai minggu ke-10 ayam Legund maupun ayam normal sama baiknya dalam memanfaatkan pakan untuk menghasilkan berat badan, seharusnya ayam Legund mempunyai kesempatan untuk menghasilkan berat badan yang lebih tinggi dibanding ayam normal. Hal ini juga menunjukkan bahwa ayam Legund maupun ayam normal mempunyai kemampuan adaptasi yang sama terhadap lingkungan kandang. Rerata temperatur kandang pada pukul $08.00,13.00$, dan 16.00 berturut-turut $22,4^{\circ} \mathrm{C}, 30,5^{\circ} \mathrm{C}$, dan $22,1^{\circ} \mathrm{C}$, sehingga cekaman panas yang terjadi hanya pada siang hari dan ternyata tidak berpengaruh terhadap berat badan yang dihasilkan. Suhu lingkungan optimum atau thermoneutral zone untuk ayam potong di Indonesia adalah 18 hingga $23^{\circ} \mathrm{C}$ (Sinurat, 1986).

Hasil penelitian Shaaban et al. (2008) melaporkan bahwa berat badan ayam Legund nyata lebih baik dari pada jenis ayam lain. Demikian juga hasil penelitian yang dilakukan oleh Galal (2008) yang melaporkan bahwa ayam Leher Gundul dengan genotip $\mathrm{Na} / \mathrm{Na}$ nyata lebih baik bobot badan pada umur 8 minggu daripada ayam bergenotip Na/na dan na/na.

\section{Pertambahan berat badan}

Rerata pertambahan berat badan ayam hasil penelitian sampai umur 8-10 minggu disajikan pada Tabel 3. Perbedaan tingkat protein pakan dengan imbangan energi yang sama berpengaruh sangat nyata $(\mathrm{P}<0,01)$ terhadap pertambahan berat badan yang dihasilkan kecuali minggu ke-2-4.

Pada Tabel 3 dapat dilihat bahwa P1 menghasilkan pertambahan berat badan yang lebih tinggi daripada pakan dengan P2 dan P3. Pakan dengan kandungan protein dan energi yang lebih tinggi memberikan kesempatan ayam dengan memanfaatkannya untuk menghasilkan pertambahan berat badan lebih tinggi. Semua anak ayam mempunyai kemampuan yang sama memanfaatkan pakan untuk mencapai tingkat pertumbuhan optimal (Sidadolog dan Yuwanta, 2011). Penyebab perbedaan pertambahan berat badan yang dihasilkan adalah perbedaan kandungan protein dan energi pakan.

Pada minggu ke-2-4 perbedaan pakan menghasilkan pertambahan berat badan yang berbeda tidak nyata. Pada minggu ke-2-4 terjadi laju pertumbuhan cepat. Semua ayam pada masingmasing perlakuan mampu memenuhi kebutuhan protein dan energi yang sama. Untuk memenuhi kebutuhan protein dan energi, P1 dengan kandungan protein dan energi yang paling rendah, maka konsumsi pakannya lebih tinggi daripada P2 dan P3. Hasilnya pertambahan berat badan pada P1, $\mathrm{P} 2$, dan P3 sama.

Perbedaan kondisi bulu menghasilkan pertambahan berat badan yang sama mulai minggu ke-0-2 sampai minggu ke-8-10. Hal ini menunjukkan bahwa ayam Legund maupun ayam normal mempunyai kemampuan adaptasi yang sama terhadap lingkungan kandang sehingga menghasilkan pertambahan berat badan yang tidak berbeda, dengan pakan yang sama seharusnya ayam Legund mempunyai kesempatan untuk menghasilkan pertambahan berat badan yang lebih tinggi dibanding ayam normal.

Cahaner et al. (1993) melaporkan bahwa ayam Legund Na/na (heterozygous) mempunyai pertambahan berat badan 3\% lebih berat dari pada ayam varietas bulu biasa, demikian juga dengan Yalcin et al. (1996) yang menyatakan bahwa pertambahan berat badan ayam varietas bulu biasa adalah 3,2\% (65 g) lebih rendah.

Pada umur starter (0-4 minggu) pengaruh pakan menghasilkan pertambahan berat badan yang berbeda nyata $(\mathrm{P}<0,05)$. Pakan $\mathrm{P} 1$ menghasilkan 
Tabel 3. Rerata pertambahan berat badan ayam (g/ekor/2 minggu) pengaruh umur, kondisi bulu dan pakan (average chicken gain (g/chicken/2 weeks) the effect of age, feather condition and feed)

\begin{tabular}{|c|c|c|c|c|c|}
\hline \multirow{2}{*}{$\begin{array}{l}\text { Umur (age) } \\
\text { (minggu) } \\
\text { (week) }\end{array}$} & \multirow{2}{*}{$\begin{array}{l}\text { Kondisi bulu } \\
\text { (feather } \\
\text { condition) }\end{array}$} & \multicolumn{3}{|c|}{ Pakan (feed) } & \multirow{2}{*}{$\begin{array}{c}\text { Rerata kondisi } \\
\text { bulu (average of } \\
\text { feather condition) }\end{array}$} \\
\hline & & P1 & $\mathrm{P} 2$ & P3 & \\
\hline \multirow{3}{*}{$0-2$} & Legund & $43,77 \pm 17,71$ & $39,85 \pm 9,98$ & $38,49 \pm 13,61$ & $40,71 \pm 13,76$ \\
\hline & Normal & $42,00 \pm 10,82$ & $44,29 \pm 14,93$ & $34,86 \pm 10,24$ & $40,38 \pm 11,99$ \\
\hline & $\begin{array}{l}\text { Rerata } \\
\text { (average)** }\end{array}$ & $42,89 \pm 14,26^{\mathrm{a}}$ & $42,07 \pm 12,45^{\mathrm{ab}}$ & $36,68 \pm 11,92^{\mathrm{c}}$ & $40,55 \pm 12,88^{\mathrm{ns}}$ \\
\hline \multirow{3}{*}{$2-4$} & Legund & $85,89 \pm 25,85$ & $82,82 \pm 20,75$ & $81,22 \pm 19,36$ & $83,31 \pm 21,99$ \\
\hline & Normal & $94,22 \pm 23,91$ & $86,04 \pm 34,25$ & $83,40 \pm 25,68$ & $87,89 \pm 27,94$ \\
\hline & $\begin{array}{l}\text { Rerata } \\
\left({\text { average })^{\mathrm{ns}}}\right.\end{array}$ & $90,05 \pm 24,88$ & $84,43 \pm 27,50$ & $82,31 \pm 22,52$ & $85,59 \pm 17,46^{\mathrm{ns}}$ \\
\hline \multirow{3}{*}{$4-6$} & Legund & $140,54 \pm 35,18$ & $125,81 \pm 25,91$ & $109,08 \pm 41,91$ & $125,15 \pm 34,33$ \\
\hline & Normal & $135,43 \pm 31,77$ & $133,08 \pm 26,15$ & $111,92 \pm 24,97$ & $126,81 \pm 27,63$ \\
\hline & $\begin{array}{l}\text { Rerata } \\
(\text { average)** }\end{array}$ & $137,98 \pm 33,47^{\mathrm{a}}$ & $129,45 \pm 26,03^{\mathrm{ab}}$ & $110,49 \pm 33,44^{\mathrm{c}}$ & $125,98 \pm 30,98^{\mathrm{ns}}$ \\
\hline \multirow{3}{*}{$6-8$} & Legund & $173,57 \pm 52,07$ & $151,87 \pm 41,95$ & $113,14 \pm 50,58$ & $146,19 \pm 48,19$ \\
\hline & Normal & $172,01 \pm 43,40$ & $159,13 \pm 52,71$ & $135,76 \pm 41,58$ & $155,63 \pm 45,89$ \\
\hline & $\begin{array}{l}\text { Rerata } \\
(\text { average)** }\end{array}$ & $172,79 \pm 47,73^{\mathrm{a}}$ & $155,50 \pm 47,33^{\mathrm{b}}$ & $124,45 \pm 46,08^{\mathrm{c}}$ & $150,91 \pm 47,06^{\mathrm{ns}}$ \\
\hline \multirow{3}{*}{$8-10$} & Legund & $181,46 \pm 57,59$ & $149,14 \pm 62,56$ & $136,39 \pm 85,44$ & $155,66 \pm 68,53$ \\
\hline & Normal & $174,58 \pm 66,90$ & $173,35 \pm 74,30$ & $160,26 \pm 45,02$ & $169,39 \pm 62,09$ \\
\hline & $\begin{array}{l}\text { Rerata } \\
\text { (average)* }\end{array}$ & $178,02 \pm 62,25^{\mathrm{a}}$ & $161,25 \pm 68,43^{\mathrm{ab}}$ & $148,32 \pm 65,23^{b}$ & $162,53 \pm 65,30^{\mathrm{ns}}$ \\
\hline \multirow{3}{*}{$\begin{array}{c}\text { 0-4 (starter) } \\
\text { (g/ekor/4 } \\
\text { minggu) } \\
\text { (g/chicken/4 } \\
\text { weeks) }\end{array}$} & Legund & $129,66 \pm 36,74$ & $122,68 \pm 26,20$ & $119,72 \pm 28,42$ & $124,02 \pm 30,46$ \\
\hline & Normal & $136,22 \pm 28,69$ & $130,33 \pm 39,67$ & $118,26 \pm 30,77$ & $128,27 \pm 33,04$ \\
\hline & $\begin{array}{l}\text { Rerata } \\
\text { (average)* }\end{array}$ & $132,94 \pm 32,72^{\mathrm{a}}$ & $126,50 \pm 32,94^{\mathrm{b}}$ & $118,99 \pm 29,59^{c}$ & $126,14 \pm 31,75^{\mathrm{ns}}$ \\
\hline \multirow{3}{*}{$\begin{array}{l}\text { 4-10 (grower) } \\
\text { (g/ekor/6 } \\
\text { minggu) } \\
\text { (g/chicken/6 } \\
\text { weeks) }\end{array}$} & Legund & $495,57 \pm 109,96$ & $426,83 \pm 102,18$ & $366,83 \pm 142,61$ & $429,74 \pm 118,25$ \\
\hline & Normal & $495,38 \pm 111,00$ & $478,26 \pm 127,10$ & $407,93 \pm 90,25$ & $460,53 \pm 109,45$ \\
\hline & $\begin{array}{l}\text { Rerata } \\
(\text { average)** }\end{array}$ & $495,48 \pm 110,48^{\mathrm{a}}$ & $452,55 \pm 114,64^{b}$ & $387,38 \pm 116,43^{\mathrm{c}}$ & $445,13 \pm 113,85^{\mathrm{ns}}$ \\
\hline
\end{tabular}

P1: 20,94\% protein : 3.139,43 kcal/kg energi, P2: 18,91\% protein : 2.839,20 kcal/kg energi, P3: 17,32\% protein : $2.596,28 \mathrm{kcal} / \mathrm{kg}$ energi.

a,b,c Superskrip yang berbeda pada baris yang sama menunjukkan perbedaan yang nyata $(\mathrm{P}<0,05)$ dan sangat nyata $(\mathrm{P}<0,01)$ (different superscripts at the same row indicate significant differences $(P<0.05)$ and highly significant $(P<0.01))$.

ns Berbeda tidak nyata (non significant).

* Berbeda nyata (significant)

** Berbeda sangat nyata (highly significant).

pertambahan berat badan tertinggi yaitu $132,94 \pm 32,72$ g/ekor/4 minggu. Pada umur grower (4-10 minggu) pakan P1 juga menghasilkan pertambahan berat badan tertinggi yaitu 495,48 $\pm 110,48$ g/ekor/6 minggu. Pakan dengan kandungan protein dan energi yang lebih tinggi dapat dimanfaatkan lebih baik untuk menghasilkan pertambahan berat badan lebih tinggi daripada pakan dengan kandungan protein dan energi yang lebih rendah. Pengaruh kondisi bulu menghasilkan pertambahan berat badan yang berbeda tidak nyata baik pada umur starter (0-4 minggu) maupun umur grower (4-10 minggu).

\section{Konsumsi pakan}

Rerata konsumsi pakan ayam hasil penelitian sampai umur 8-10 minggu disajikan pada Tabel 4 . Pemunculan interaksi antara pengaruh tingkat 
protein dengan imbangan energi yang sama dan pengaruh kondisi bulu pada konsumsi pakan tidak terjadi seperti yang diharapkan. Hal ini menunjukkan bahwa ayam Legund mempunyai respon yang sama dengan ayam normal terhadap pengaruh tingkat protein dengan imbangan energi yang sama pada konsumsi pakan. Pembahasan selanjutnya dilakukan pada faktor pengaruh perbedaan tingkat protein pakan dengan imbangan energi yang sama dan faktor pengaruh perbedaan bulu.
Perbedaan tingkat protein pakan dengan imbangan energi yang sama berpengaruh sangat nyata $(\mathrm{P}<0,01)$ terhadap konsumsi pakan sampai minggu ke-4-6. Pada Tabel 4 diperlihatkan bahwa perbedaan tingkat protein dan energi menyebabkan perbedaan tingkat konsumsi pakannya. Pakan dengan tingkat protein dan energi lebih rendah, maka konsumsi pakannya lebih banyak daripada pakan dengan tingkat protein dan energi yang lebih tinggi. Hal ini ditunjukkan pada pakan dengan

Tabel 4. Rerata konsumsi pakan ayam (g/ekor/2 minggu) pengaruh umur, kondisi bulu dan pakan (average chicken consumption (g/chicken/2 weeks) the effect of age, feather condition and feed)

\begin{tabular}{|c|c|c|c|c|c|}
\hline \multirow{2}{*}{$\begin{array}{c}\begin{array}{c}\text { Umur }(\text { age }) \\
(\text { minggu }) \\
(\text { week })\end{array}\end{array}$} & \multirow{2}{*}{$\begin{array}{l}\text { Kondisi bulu } \\
\text { (feather } \\
\text { condition) }\end{array}$} & \multicolumn{3}{|c|}{ Pakan (feed) } & \multirow{2}{*}{$\begin{array}{c}\text { Rerata kondisi } \\
\text { bulu (average of } \\
\text { feather condition) }\end{array}$} \\
\hline & & $\mathrm{P} 1$ & $\mathrm{P} 2$ & P3 & \\
\hline \multirow{3}{*}{$0-2$} & Legund & $86,78 \pm 19,84$ & $98,46 \pm 11,14$ & $116,54 \pm 22,65$ & $100,59 \pm 17,87$ \\
\hline & Normal & $97,59 \pm 9,38$ & $108,30 \pm 7,78$ & $105,84 \pm 12,00$ & $103,91 \pm 9,72$ \\
\hline & $\begin{array}{l}\text { Rerata } \\
\text { (average)** }\end{array}$ & $92,19 \pm 14,61^{\mathrm{a}}$ & $103,38 \pm 9,46^{\mathrm{bc}}$ & $111,19 \pm 17,33^{\mathrm{c}}$ & $102,25 \pm 13,79^{\mathrm{ns}}$ \\
\hline \multirow{3}{*}{$2-4$} & Legund & $202,20 \pm 50,81$ & $237,33 \pm 33,22$ & $287,42 \pm 63,73$ & $242,32 \pm 49,25$ \\
\hline & Normal & $248,59 \pm 32,86$ & $265,74 \pm 43,59$ & $291,58 \pm 61,27$ & $268,64 \pm 45,91$ \\
\hline & $\begin{array}{l}\text { Rerata } \\
\text { (average)** }\end{array}$ & $225,39 \pm 41,84^{\mathrm{a}}$ & $251,54 \pm 38,40^{\mathrm{bc}}$ & $289,49 \pm 62,50^{\mathrm{c}}$ & $255,48 \pm 47,58^{\text {ns }}$ \\
\hline \multirow{3}{*}{$4-6$} & Legund & $378,73 \pm 54,69$ & $399,92 \pm 62,61$ & $435,34 \pm 61,19$ & $404,66 \pm 59,50$ \\
\hline & Normal & $384,17 \pm 47,55$ & $436,46 \pm 33,41$ & $475,58 \pm 63,04$ & $432,07 \pm 47,99$ \\
\hline & $\begin{array}{l}\text { Rerata } \\
\text { (average)** }\end{array}$ & $381,45 \pm 51,12^{\mathrm{a}}$ & $418,19 \pm 48,01^{\mathrm{b}}$ & $455,46 \pm 62,12^{\mathrm{c}}$ & $418,37 \pm 53,75^{\mathrm{ns}}$ \\
\hline \multirow{3}{*}{$6-8$} & Legund & $567,87 \pm 147,74$ & $598,14 \pm 149,87$ & $514,86 \pm 65,82$ & $560,29 \pm 121,14$ \\
\hline & Normal & $605,61 \pm 139,23$ & $616,72 \pm 152,95$ & $625,93 \pm 142,88$ & $616,08 \pm 145,02$ \\
\hline & $\begin{array}{l}\text { Rerata } \\
{\text { (average })^{\mathrm{ns}}}\end{array}$ & $586,74 \pm 143,49$ & $607,43 \pm 151,41$ & $570,39 \pm 104,35$ & $588,19 \pm 133,08^{\mathrm{ns}}$ \\
\hline \multirow{3}{*}{$8-10$} & Legund & $673,15 \pm 73,17$ & $575,65 \pm 46,55$ & $590,30 \pm 118,62$ & $613,03 \pm 79,45^{\mathrm{a}}$ \\
\hline & Normal & $736,38 \pm 96,03$ & $748,19 \pm 187,49$ & $734,17 \pm 150,75$ & $739,58 \pm 144,76^{\mathrm{b}}$ \\
\hline & $\begin{array}{l}\text { Rerata } \\
{\text { (average })^{\mathrm{ns}}}\end{array}$ & $704,77 \pm 84,59$ & $661,92 \pm 117,02$ & $662,24 \pm 134,69$ & $676,31 \pm 112,10 * *$ \\
\hline \multirow{3}{*}{$\begin{array}{c}0-4 \text { (starter) } \\
\text { (g/ekor/4 } \\
\text { minggu) } \\
\text { (g/chicken } / 4 \\
\text { weeks) }\end{array}$} & Legund & $288,98 \pm 65,91$ & $335,79 \pm 38,99$ & $403,95 \pm 77,81$ & $342,91 \pm 60,90$ \\
\hline & Normal & $346,19 \pm 28,56$ & $374,04 \pm 44,84$ & $397,43 \pm 63,12$ & $372,55 \pm 45,51$ \\
\hline & $\begin{array}{l}\text { Rerata } \\
(\text { average)** }\end{array}$ & $317,59 \pm 47,23^{\mathrm{a}}$ & $354,92 \pm 41,92^{\mathrm{bc}}$ & $400,69 \pm 70,46^{\mathrm{c}}$ & $357,73 \pm 53,20^{\mathrm{ns}}$ \\
\hline \multirow{3}{*}{$\begin{array}{c}\text { 4-10 (grower) } \\
\text { (g/ekor/6 } \\
\text { minggu) } \\
\text { (g/chicken/6 } \\
\text { weeks) }\end{array}$} & Legund & $1619,76 \pm 229,69$ & $1573,71 \pm 226,57$ & $1540,50 \pm 135,88$ & $1577,99 \pm 197,38^{a}$ \\
\hline & Normal & $1726,15 \pm 203,72$ & $1801,37 \pm 92,82$ & $1835,68 \pm 114,46$ & $1787,73 \pm 137,00^{\mathrm{b}}$ \\
\hline & $\begin{array}{l}\text { Rerata } \\
{\text { (average })^{\mathrm{ns}}}\end{array}$ & $1672,95 \pm 216,71$ & $1687,54 \pm 159,69$ & $1688,09 \pm 125,17$ & $1682,86 \pm 167,19 * *$ \\
\hline
\end{tabular}

P1: 20,94\% protein : $3.139,43 \mathrm{kcal} / \mathrm{kg}$ energi, $\mathrm{P} 2: 18,91 \%$ protein : 2.839,20 kcal/kg energi, P3: 17,32\% protein : $2.596,28 \mathrm{kcal} / \mathrm{kg}$ energi.

a,b,c Superskrip yang berbeda pada baris dan kolom yang sama menunjukkan perbedaan yang nyata $(\mathrm{P}<0,05)$ dan sangat nyata $(\mathrm{P}<0,01)$ (different superscripts at the same row and column indicate significant differences $(P<0.05)$ and highly significant $(P<0.01))$.

ns Berbeda tidak nyata (non significant).

** Berbeda sangat nyata (highly significant). 
tingkat protein $17 \%$ dan energi $2.596 \mathrm{kcal} / \mathrm{kg}$ membutuhkan pakan dalam jumlah yang paling banyak untuk memenuhi kebutuhan pertumbuhan. Ayam akan mengkonsumsi pakan sampai kebutuhan nutriennya tercukupi terutama energi.

Semakin rendah kandungan protein-energi pakan, maka konsumsi pakan akan lebih tinggi agar kebutuhan protein-energi untuk pertumbuhan dapat tercapai (Sidadolog, 2009), selanjutnya pada pakan yang memenuhi kualitas berdasarkan kebutuhan untuk pertumbuhan, maka konsumsi pakan akan disesuaikan dengan perbedaan konsentrasi protein-energi pakan. Zuprizal (2006) menyatakan bahwa pakan yang rendah kandungan energi termetabolisnya akan meningkatkan jumlah pakan yang dikonsumsi dan sebaliknya pakan yang tinggi kandungan energi termetabolisnya akan menyebabkan turunnya jumlah konsumsi pakan.

Pakan dengan kandungan protein-energi yang rendah mempunyai kepadatan nutrien yang rendah dibandingkan pakan dengan kandungan protein tinggi (Rosandi, 2005). Oleh karena itu pada perlakuan pakan dengan tingkat protein-energi rendah, maka ayam akan mengkonsumsi pakan yang lebih banyak untuk mencukupi kebutuhannya.

Data minggu ke-6-8 dan ke-8-10 menunjukkan bahwa perbedaan tingkat protein pakan dengan imbangan energi yang sama berpengaruh tidak nyata terhadap konsumsi pakan. Hal ini menunjukkan bahwa pada minggu tersebut protein pakan $17,32 \%$ dan energi $2.596,28 \mathrm{kcal} / \mathrm{kg}$ sudah cukup untuk memenuhi kebutuhan ayam untuk pertumbuhan.

Perbedaan kondisi bulu memberikan pengaruh yang berbeda tidak nyata pada konsumsi pakan kecuali pada minggu ke-8-10. Hal ini menunjukkan bahwa sampai minggu ke-6-8 ayam Legund membutuhkan pakan yang sama jumlahnya dengan ayam normal untuk pertumbuhan sedangkan data minggu ke-8-10 berbeda nyata $(\mathrm{P}<0,05)$. Ayam normal lebih banyak konsumsi pakannya dibanding dengan ayam Legund. Ayam Legund lebih lancar dalam pengeluaran panas dibandingkan dengan ayam normal. Oleh karena itu ayam normal mengeluarkan panas lebih banyak dibandingkan dengan ayam Legund sehingga energi yang dibutuhkan lebih banyak, maka konsumsi pakan ayam normal lebih banyak daripada ayam Legund.

Pada umur starter (0-4 minggu) pengaruh pakan menunjukkan perbedaan yang sangat nyata $(\mathrm{P}<0,01)$ pada konsumsi pakan yang dihasilkan. Pakan P3 konsumsi pakannya tertinggi yaitu $400,69 \pm 70,46$ g/ekor/4 minggu sedangkan pada umur grower (4-10 minggu) pengaruh pakan menunjukkan perbedaan yang tidak nyata pada konsumsi pakan yang dihasilkan. Peningkatan konsumsi pakan karena kandungan protein dan energi yang lebih rendah untuk mencukupi kebutuhan nutrien hanya terjadi pada umur starter, sedangkan pada grower pakan P3 sudah sesuai dengan kebutuhan nutrien sehingga konsumsi pakannya berbeda tidak nyata. Pada umur starter (0-4 minggu) pengaruh kondisi bulu menunjukkan perbedaan yang sama pada konsumsi pakan, sedangkan pada umur grower (4-10 minggu) perbedaan kondisi bulu menunjukkan perbedaan yang sangat nyata $(\mathrm{P}<0,01)$ pada konsumsi pakan, konsumsi pakan ayam Legund yaitu $1577,99 \pm 197,38$ g/ekor/6 minggu lebih rendah daripada ayam normal yaitu $1787,73 \pm 137,00$ g/ekor/6 minggu. Keunggulan ayam Legund terlihat pada umur grower yang ditunjukkan dengan konsumsi pakan yang lebih sedikit daripada ayam normal karena kebutuhan energinya juga lebih sedikit.

\section{Konversi pakan}

Rerata konversi pakan ayam hasil penelitian sampai umur 8-10 minggu disajikan pada Tabel 5. Pemunculan interaksi antara pengaruh tingkat protein dengan imbangan energi yang sama dan pengaruh kondisi bulu tidak terjadi pada konversi pakan ayam Legund dan ayam normal. Hal ini menunjukkan bahwa keterkaitan antara ketiga perlakuan pakan dan kondisi bulu terhadap konversi pakan sangat kecil, sehingga tidak kelihatan dalam penelitian ini.

Perbedaan tingkat protein pakan dengan imbangan energi yang sama berpengaruh sangat nyata $(\mathrm{P}<0,01)$ terhadap konversi pakan sampai minggu ke-6-8. Pada Tabel 5 dapat dilihat bahwa pakan dengan tingkat protein dan energi lebih tinggi, maka akan menghasilkan konversi yang lebih rendah daripada pakan dengan tingkat protein dan energi yang lebih rendah. Hal ini menunjukkan pakan dengan tingkat protein dan energi lebih tinggi mampu dimanfaatkan dengan baik untuk menghasilkan pertambahan berat badan lebih tinggi dibandingkan pakan dengan tingkat protein dan energi lebih rendah.

Data minggu ke-8-10 menunjukkan bahwa perbedaan pakan memberikan hasil yang sama terhadap konversi pakan. Hubungan antara konsumsi pakan dan pertambahan berat badan ditentukan oleh konversi pakan. Perlakuan pakan dengan konsentrasi protein-energi rendah akan menghasilkan konversi pakan yang lebih tinggi dibandingkan dengan perlakuan konsentrasi protein-energi pakan sedang dan tinggi (Sidadolog dan Yuwanta, 2011).

Pengaruh kondisi bulu memberikan hasil yang sama terhadap konversi pakan, dimana konversi pakan ayam normal sama nilainya dengan ayam Legund. Seharusnya nilai konversi pakan 
Tabel 5. Rerata konversi pakan ayam pengaruh umur (g/ekor/2 minggu), kondisi bulu dan pakan (average chicken convertion ( $\mathrm{g} /$ chicken/2 weeks) the effect of age, feather condition and feed)

\begin{tabular}{|c|c|c|c|c|c|}
\hline \multirow{2}{*}{$\begin{array}{c}\text { Umur (age) } \\
\text { (minggu) } \\
\text { (week) }\end{array}$} & \multirow{2}{*}{$\begin{array}{c}\text { Kondisi bulu } \\
\text { (feather } \\
\text { condition) }\end{array}$} & \multicolumn{3}{|c|}{ Pakan $(f e e d)$} & \multirow{2}{*}{$\begin{array}{c}\text { Rerata kondisi } \\
\text { bulu (average of } \\
\text { feather condition) }\end{array}$} \\
\hline & & $\mathrm{P} 1$ & $\mathrm{P} 2$ & P3 & \\
\hline \multirow{3}{*}{$0-2$} & Legund & $2,04 \pm 0,43$ & $2,49 \pm 0,36$ & $3,02 \pm 0,45$ & $2,52 \pm 0,42$ \\
\hline & Normal & $2,39 \pm 0,44$ & $2,54 \pm 0,49$ & $3,15 \pm 0,71$ & $2,69 \pm 0,55$ \\
\hline & $\begin{array}{l}\text { Rerata } \\
(\text { average)** }\end{array}$ & $2,22 \pm 0,44^{\mathrm{a}}$ & $2,51 \pm 0,43^{\mathrm{b}}$ & $3,08 \pm 0,58^{\mathrm{c}}$ & $2,60 \pm 0,48^{\mathrm{ns}}$ \\
\hline \multirow{3}{*}{$2-4$} & Legund & $2,35 \pm 0,31$ & $2,91 \pm 0,52$ & $3,51 \pm 0,52$ & $2,93 \pm 0,45$ \\
\hline & Normal & $2,66 \pm 0,32$ & $3,29 \pm 0,86$ & $3,58 \pm 0,58$ & $3,18 \pm 0,59$ \\
\hline & $\begin{array}{l}\text { Rerata } \\
(\text { average)** }\end{array}$ & $2,50 \pm 0,31^{\mathrm{a}}$ & $3,10 \pm 0,69^{\mathrm{b}}$ & $3,55 \pm 0,55^{\mathrm{c}}$ & $3,05 \pm 0,52^{\mathrm{ns}}$ \\
\hline \multirow{3}{*}{$4-6$} & Legund & $2,71 \pm 0,27$ & $3,17 \pm 0,34$ & $3,99 \pm 0,40$ & $3,29 \pm 0,36$ \\
\hline & Normal & $2,96 \pm 0,41$ & $3,29 \pm 0,19$ & $4,28 \pm 0,63$ & $3,51 \pm 0,41$ \\
\hline & $\begin{array}{l}\text { Rerata } \\
\text { (average)** }\end{array}$ & $2,84 \pm 0,34^{\mathrm{a}}$ & $3,23 \pm 0,27^{\mathrm{b}}$ & $4,13 \pm 0,55^{\mathrm{c}}$ & $3,40 \pm 0,39^{\text {ns }}$ \\
\hline \multirow{3}{*}{$6-8$} & Legund & $3,29 \pm 0,67$ & $3,98 \pm 1,13$ & $4,63 \pm 0,89$ & $3,97 \pm 0,89$ \\
\hline & Normal & $3,65 \pm 1,12$ & $3,91 \pm 0,97$ & $4,72 \pm 1,21$ & $4,09 \pm 1,10$ \\
\hline & $\begin{array}{l}\text { Rerata } \\
\text { (average)** }\end{array}$ & $3,48 \pm 0,89^{\mathrm{a}}$ & $3,95 \pm 1,05^{\mathrm{bc}}$ & $4,67 \pm 1,05^{\mathrm{c}}$ & $4,03 \pm 0,99^{\mathrm{ns}}$ \\
\hline \multirow{3}{*}{$8-10$} & Legund & $3,82 \pm 0,84$ & $4,37 \pm 1,97$ & $4,74 \pm 1,11$ & $4,31 \pm 1,31$ \\
\hline & Normal & $4,26 \pm 0,71$ & $4,56 \pm 1,38$ & $4,71 \pm 1,35$ & $4,51 \pm 1,15$ \\
\hline & $\begin{array}{l}\text { Rerata } \\
\text { (average) }^{\mathrm{ns}}\end{array}$ & $4,04 \pm 0,78$ & $4,46 \pm 1,68$ & $4,73 \pm 1,23$ & $4,41 \pm 1,23^{\mathrm{ns}}$ \\
\hline \multirow[b]{2}{*}{$\begin{array}{c}0-4 \\
\text { (starter) }\end{array}$} & Legund & $2,23 \pm 0,36$ & $2,75 \pm 0,36$ & $3,35 \pm 0,50$ & $2,78 \pm 0,41$ \\
\hline & $\begin{array}{l}\text { Normal } \\
\text { Rerata } \\
(\text { average)** }\end{array}$ & $\begin{array}{l}2,56 \pm 0,31 \\
2,39 \pm 0,33^{\mathrm{a}}\end{array}$ & $\begin{array}{l}2,95 \pm 0,42 \\
2,85 \pm 0,39^{b}\end{array}$ & $\begin{array}{l}3,44 \pm 0,59 \\
3,39 \pm 0,55^{\mathrm{c}}\end{array}$ & $\begin{array}{l}2,98 \pm 0,44 \\
2,88 \pm 0,42^{\mathrm{ns}}\end{array}$ \\
\hline \multirow{3}{*}{$\begin{array}{c}4-10 \\
\text { (grower) }\end{array}$} & Legund & $3,28 \pm 0,41$ & $3,75 \pm 0,70$ & $4,36 \pm 0,56$ & $3,79 \pm 0,56$ \\
\hline & Normal & $3,64 \pm 0,66$ & $3,95 \pm 0,66$ & $4,56 \pm 0,63$ & $4,05 \pm 0,65$ \\
\hline & $\begin{array}{l}\text { Rerata } \\
\text { (average)** }\end{array}$ & $3,46 \pm 0,53^{\mathrm{a}}$ & $3,85 \pm 0,68^{b}$ & $4,46 \pm 0,59^{\mathrm{c}}$ & $3,92 \pm 0,60^{\text {ns }}$ \\
\hline
\end{tabular}

P1: 20,94\% protein : $3.139,43 \mathrm{kcal} / \mathrm{kg}$ energi, $\mathrm{P} 2: 18,91 \%$ protein $: 2.839,20 \mathrm{kcal} / \mathrm{kg}$ energi, $\mathrm{P} 3: 17,32 \%$ protein : $2.596,28 \mathrm{kcal} / \mathrm{kg}$ energi.

a,b,c Superskrip yang berbeda pada baris yang sama menunjukkan perbedaan yang nyata $(\mathrm{P}<0,05)$ dan sangat nyata $(\mathrm{P}<0,01)$ (different superscripts at the same row indicate significant differences $(P<0.05)$ and highly significant $(P<0.01))$.

ns Berbeda tidak nyata (non significant).

** Berbeda sangat nyata (highly significant).

ayam Legund lebih rendah daripada ayam normal karena ayam normal membutuhkan pakan lebih banyak.

Dilihat dari umur ayam, semakin tua ayam, maka nilai konversinya semakin besar. Hal ini menunjukkan bahwa semakin bertambah umur, maka ayam semakin membutuhkan pakan yang lebih banyak untuk hidup pokok dan pertumbuhan. Berri et al. (2005) menyatakan bahwa nilai konversi makanan akan berbeda dari masa awal ke masa akhir karena di masa akhir pertumbuhan ayam menjadi lambat atau mulai menurun setelah mencapai umur tertentu, sedangkan konsumsi pakan dapat terus meningkat. Bila ketersediaan nutrien dalam pakan tercukupi, maka akan menaikkan berat badan dan menyebabkan konversi pakan menjadi lebih baik.

Pada umur starter (0-4 minggu) pengaruh pakan menunjukkan perbedaan yang sangat nyata $(\mathrm{P}<0,01)$ pada konversi pakan. Pakan dengan tingkat protein $20,94 \%$ dan energi $3.139,43 \mathrm{kcal} / \mathrm{kg}$ 


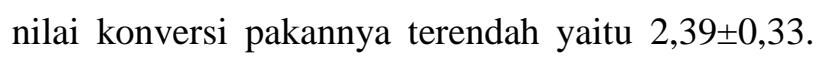
Demikian juga pada umur grower (4-10 minggu) yaitu $3,46 \pm 0,53$. Pengaruh kondisi bulu tidak menunjukkan perbedaan yang nyata pada konversi pakan baik pada umur starter (0-4 minggu) maupun umur grower (4-10 minggu). Hal ini menunjukkan konversi pakan ayam Legund tidak berbeda dengan ayam normal.

\section{Kesimpulan}

Pakan dengan imbangan protein-energi $20,94 \%$ dan energi $3.139,43 \mathrm{kcal} / \mathrm{kg}$ paling baik untuk menghasilkan berat badan dan pertambahan berat badan ayam Legund maupun ayam normal sampai umur 10 minggu. Pertumbuhan ayam Legund sama dengan ayam normal sampai umur 10 minggu. Pemunculan interaksi antara pengaruh tingkat protein dengan imbangan energi yang sama dan pengaruh kondisi bulu tidak terjadi pada konsumsi dan konversi pakan ayam Legund dan ayam normal sampai umur 10 minggu.

\section{Daftar Pustaka}

Berri, C., M. Debut, C. Santé-Lhoutellier, B. Arnould, B. Boutten, N. Sellier, E. Baéza, N. Jehl, Y. Jégo, M. J. Duclos and E. Le BihanDuval. 2005. Variations in chicken breast meat quality: A strong implication of struggle and muscle glycogen level at death. Br. Poult. Sci. 46: 572-579.

Bregendahl, K., J. L. Sell and D. R. Zimmerman. 2002. Effect of low-protein diets on growth performance and body composition of broiler chicks. Poult. Sci. 81: 1156-1167.

Cahaner, A., N. Deeb and M. Gutman. 1993. Effect of plumage-reducing Naked-Neck (na) gen on the performance of fast growing broilers at normal and high ambient temperatures. Poult. Sci. 72: 767-775.

Dewi, G. A. M. K. dan I. W. Wijana. 2011. Pengaruh Penggunaan Level Energi-Protein Ransum terhadap Produksi Ayam Kampung. The Excelence Research Universitas Udayana. Denpasar.

Dewi, G. A. M. K., I. G. Mahardika, I. K. Sumadi, I. M. Suasta, dan I. M. Wirapartha. 2009. Peningkatan produktivitas ayam kampung melalui kebutuhan energi dan protein pakan. Laporan Penelitian Hibah Bersaing, Fakultas Peternakan, Universitas Udayana. Denpasar.

Ditjenak. 2012. Statistik Peternakan dan Kesehatan Hewan 2012. Direktorat Jenderal Peternakan dan Kesehatan Hewan, Kementerian Pertanian Republik Indonesia. Jakarta.
Galal, A. 2008. Immunocompetence and somehematological parameters of Naked Neck and normally feathered chicken. J. Poult. Sci. 45: 89-95.

Nitis, I. M. 2006. Peternakan Berwawasan Kebudayaan. Cetakan Pertama, Arti Foundation. Denpasar.

Rosandi, H. 2005. Performa ayam broiler yang diberi pakan berbeda dengan rasio yang sama. Skripsi Program S1. Fakultas Peternakan, Universitas Gadjah Mada. Yogyakarta.

Shaaban, G. F., E. E. Ahmed and M. Mezes. 2008. Efect of breed, heterosis and sex on body weight, and glutathione peroxidase activities in red blood cell haemolysate and blood plasma at the age of sexual maturity in chickens. J. Poult. Sci. 45: 180-185.

Sidadolog, J. H. P. 1991. Pengaruh gen Na (Naked Neck) terhadap pertumbuhan ayam kampung. Laporan Penelitian. Fakultas Peternakan, Universitas Gadjah Mada. Yogyakarta.

Sidadolog, J. H. P. 2001. Manajemen Ternak Unggas. Laboratorium Ternak Unggas. Fakultas Peternakan, Universitas Gadjah Mada. Yogyakarta.

Sidadolog, J. H. P. 2009. Ayam lokal di Indonesia. Dalam: Ayam Lokal Indonesia: Dari Plasma Nutfah Menuju Ketahanan Pangan. Sidadolog, J. H. P. (ed). CV. Bawah Sadar. Yogyakarta.

Sidadolog, J. H. P. dan T. Yuwanta. 2011. Pengaruh konsentrasi protein-energi pakan terhadap pertambahan berat badan, efisiensi energi dan efisiensi protein pada masa pertumbuhan ayam Merawang. Anim. Prod. 11: 15-22.

Sinurat, A. P. 1986. The effect of high ambient temperature on broiler growth and some plasma growth-related hormone profiles. Phd. Thesis. University of Sydney, Camden, NSW. Australia.

Swennen, Q., G. P. J. Janssens, E. Decuypere and J. Buyse. 2004. Effect of substitution between fat and protein on feed intake and its regulatory mechanisms in broiler chicken: Energy and protein metabolism and dietinduced thermogenesis. Poult. Sci. 83: 731-742.

Yalcin, S., S. Ozkan, Z. Acikgos and K. Ozkan. 1996. Effect of dietary protein content on live and carcass performance of heterozygous Naked-Neck and normally feathered broilers. Br. Poult. Sci. 37: 963-969.

Zakaria, S. 2004. Performa ayam buras fase dara yang dipelihara secara intensif dan semi intensif dengan tingkat kepadatan kandang yang berbeda. Buletin Nutrisi dan Makanan Ternak 5: 41-51. 
Zuprizal. 2006. Nutrisi Unggas. Handout. Jurusan Nutrisi dan Makanan Ternak, Fakultas Peternakan, Universitas Gadjah Mada. Yogyakarta. 